\title{
Introduction
}

\section{Democracy and democratisation}

Since the early 1970s a 'third wave' of democratisation has swept the world. In the period 1972-94 the number of democratic political systems doubled from 44 to 107 . And by the mid-1990s 58 per cent of the world's states had adopted democratic governments. ${ }^{1}$ These momentous developments have led political scientists to re-examine the theoretical literature on democratisation, and to compare the current transitions in the post-communist bloc with earlier transitions in Latin America and Southern Europe. From my reading of this literature three major schools can be identified.

One school has focused on the preconditions necessary for the emergence of stable democracy:

1 modernisation, industrialisation, urbanisation, education, capitalism and wealth; ${ }^{2}$

2 the nature of classes and the class structure, with a focus on the positive role of the bourgeoisie or the proletariat; ${ }^{3}$

3 a democratic political culture and civil society; ${ }^{4}$

4 the importance of institutional factors, ${ }^{5}$ electoral systems, ${ }^{6}$ type of regime - parliamentary or presidential, ${ }^{7}$ the development of strong parties, and a stable party system;

5 a unified state, agreed borders and the absence of ethnic and religious conflict; ${ }^{9}$

6 external factors: a peaceful international environment, the impact of globalisation. ${ }^{10}$

A second school has centred its research on the transition process. Here scholars argue that the very nature of the transition itself largely determines the success or failure of democratisation. ${ }^{11}$ 'Revolutions from above' are contrasted with 'revolutions from below'. A major focus for this school is the role of elites and the importance of elite unity, settlements and 
pacts. ${ }^{12}$ From this perspective, democratic transitions and breakdown can best be understood by examining changes in the internal relations of national elites. For Higley and Gunther, 'what principally distinguishes unconsolidated from consolidated democracies, is in short, the absence of elite consensual unity'. ${ }^{13}$ For a democratic system to persist and flourish, elites must engage in 'politics as bargaining' rather than 'politics as war'. Democratic transitions are the result of negotiated pacts between actors in the dominant elite leading either to sharing with, or conceding power to, ascendant elites. ${ }^{14}$

A third school focuses on the period after the collapse of the old regime and the problems associated with the consolidation of democracy, which we discuss further below. ${ }^{15}$

In contrast to the first school with its stress on socio-economic and other structural preconditions, the second and third schools stress the independent role of individual actors and human agency and the ability of elites to craft democracy, even where pre-conditions are unfavourable. ${ }^{16}$

Each of these three approaches has made a positive contribution to the field. However, there are two major omissions in the transition literature. First, the focus of all three schools has largely been on national-level politics. None of the above authors has devoted more than passing attention to the importance of democratisation at the regional and local levels. Second, the relationship between federalism and democracy has largely been overlooked in the transition literature. ${ }^{17}$

This study seeks to redress this imbalance by moving the focus of research from the national level to the vitally important processes of institution building and democratisation at the local level and to the study of federalism in Russia. I believe that the insights garnered in the study of the democratisation process of separate countries can be applied equally fruitfully to individual regions within countries, especially in such a large and diverse country as Russia.

Many authors have alluded to the unique nature of Russia's dual transition and its difficult task of simultaneously reforming its economy and polity. But there is in fact a third transition under way in Russia that is of no less importance, the need to reconfigure central-local relations and to create a stable and viable form of federalism. Federal states are much more difficult to set up than unitary ones. And forging a new federal system at the same time as privatising the economy and trying to radically overhaul the political system has clearly made Russia's transition triply difficult.

\section{Defining democracy}

There are many competing definitions of democracy. Perhaps the most famous is that of Robert Dahl who lists the following eight 'institutional 
guarantees' which citizens must enjoy before a country can be classified as a democracy:

1) Freedom to form and join organisations, 2) freedom of expression, 3) right to vote, 4) eligibility for public office, 5) right of political leaders to compete for support, 5a) right of political leaders to compete for votes, 6) alternative sources of information, 7) free and fair elections, 8) institutions for making government policies depend on votes and other expressions of preference. ${ }^{18}$

Dahl groups these eight factors into the following three essential attributes of a democratic polity:

1) Meaningful and extensive competition among individuals and organized groups (especially political parties) for all effective positions of government power, at regular intervals and excluding the use of force;

2) a 'highly inclusive' level of political participation in the selection of leaders and policies, at least through regular and fair elections, such that no major (adult) social group is excluded;

3) a level of civil and political liberties - freedom of expression, freedom of the press, freedom to form and join organizations - sufficient to ensure the integrity of political competition and participation. ${ }^{19}$

Dahl argued that there was no country where all of his eight conditions were fully satisfied thus; he preferred to call such states 'polyarchies', leaving the term democracy for the non-existent, ideal type. ${ }^{20}$

Dahl's eight conditions for polyarchy have been criticised for not taking into consideration the importance of such institutional features as 'parliamentarism or presidentialism, centralism or federalism, majoritarianism or consensualism' and for its silence over the degree to which governments 'are responsive or accountable to citizens between elections, and the degree to which the rule of law extends over the country's geographic and social terrain'.$^{21}$ Thus, $\mathrm{O}^{\prime}$ Donnell argues that two further conditions must be met before a country can be considered democratic: '1) elected officials should not be arbitrarily terminated before the end of their constitutionally mandated terms; 2) elected authorities should not be subject to severe constraints, vetoes, or exclusion from certain policy domains by other, nonelected actors, especially the armed forces' ${ }^{22}$

Beetham takes up many of these issues in his excellent studies of democracy. For Beetham there are two major features of democracy, 'political equality' and 'popular control'. Political equality 'is realised to the extent that there exists an equality of votes between electors, and equal right to stand for public office, an equality in the conditions for making one's voice heard and in treatment at the hands of legislators' ${ }^{23}$

Popular control has four major dimensions which build on and extend many of Dahl's original eight preconditions for polyarchy:

1) The popular election of the parliament or legislature and the head of government; 2) Open and accountable government, and the continuous 
political, legal, and financial accountability of government directly, to the electorate; 3) Guaranteed civil and political rights or liberties: freedoms of speech, association, assembly and movement, and the right to due legal process; 4) A lively civil society. ${ }^{24}$

\section{Democratic consolidation}

During the past quarter of a century, more than sixty countries around the world have made the transition from authoritarian rule to some kind of democratic regime. But as Schedler notes, 'sustaining democracy is often a task as difficult as establishing it' ${ }^{\prime 25}$ Thus, political scientists have turned their attention to democratic consolidation. As Beetham notes, 'the process of consolidating democracy which begins where the transition to democracy ends, i.e., with the inauguration of a new government at the first free and fair elections ... is a much more lengthy and difficult process than the transition itself ${ }^{\prime 26}$

The installation of democratic institutions and the ratification of a democratic constitution are but the first of many essential steps on the path to consolidation. Thus, as O'Donnell notes, a democracy may only be considered consolidated, 'when a society frees itself from the spells cast by authoritarian demagogues and rejects all alternatives to such democracy so as to no longer imagine any other possible regime' ${ }^{27}$ And in a similar vein for Linz and Stepan consolidation comes about, when 'democracy as a complex system of institutions, rules, and patterned incentives and disincentives has become, in a phrase, "the only game in town"'.28

Consolidation, however, should not be mistaken for merely the stability or longevity of a regime. Consolidation requires a deepening and broadening of democracy, a 'depth of institutionalisation reaching beyond the electoral process itself'. ${ }^{29}$ As Schedler notes, 'it implies constructing all those big organisations that make up the characteristic infrastructure of modern liberal democracies: parties, and party systems, legislative bodies, state bureaucracies, judicial systems, and systems of interest intermediation'.$^{30}$ And consolidation is only completed, 'when the authority of fairly elected government and legislative officials is properly established (i.e., not limited) and when major political actors as well as the public at large expect the democratic regime to last well into the foreseeable future' ${ }^{31}$

But how do we know a consolidated democracy when we see one, and what are the preconditions that are necessary for the creation of a consolidated democracy? In answer to the first question, Huntington put forward his two 'turnover test', whereby a democracy can be said to be consolidated when there have been two consecutive changes of government through free and fair elections. ${ }^{32}$ However, there are problems here when the same party is democratically elected repeatedly over a number 
of elections, as was the case in Japan or Italy. If there are free and fair elections but no turnover of parties does this mean a democracy is not consolidated? Surely not!

In answer to the second question, most scholars agree that the preconditions needed to consolidate a democracy may not necessarily be the same as those which brought it about in the first place. Linz and Stepan, following Rustow, stress that no democracy can be consolidated until consensus has been reached over national unity and any contested boundaries of the state have been settled. 'Consolidated democracy needs a state ... no state no democracy' ${ }^{33}$ Second, they argue no state can consolidate its democracy unless it already satisfies all of Dahl's criteria for democracy listed above. With these preliminary conditions in place Linz and Stepan posit five addition prerequisites which a democratic state must satisfy before it can be considered consolidated:

1) the development of a free and lively civil society; 2) a relatively autonomous political society; 3 ) throughout the territory of the state all major political actors ... must be effectively subjected to a rule of law that protects individual freedoms and associational life; 4) there must be a state bureaucracy that is usable by the new democratic government; 5) there must be an institutionalised economic society. ${ }^{34}$

Finally, as Gitelman notes, 'democracy should not be seen as an absolute, but as a spectrum'. Some states are more democratic than others 'and the same system may vary over time in the extent to which it is democratic' ${ }^{35}$ Moreover, as we shall show in this study, levels of democracy and authoritarianism in different regions within one country may also vary considerably.

\section{Federalism}

Writing in 1987 Elazar noted, that a 'federalist revolution' was sweeping the world 'changing the face of the globe in our time'. ${ }^{36}$ And as a result of this largely unnoticed revolution some 40 per cent of the world's population now reside in federal states, and another third live in polities that are governed by some form of federal arrangements. Moreover, as Smith observes, with the collapse of communism, federalism has been, 'propelled into occupying a more central place by the resurgence of nationalist and ethnic tensions which have paralleled, if not taken sustenance from the end of the Cold War'. ${ }^{37}$

Following Watts, it is important to distinguish between: 'federalism', 'federal political systems' and 'federations'. Federalism is a normative concept, an ideology which advocates, 'multi-tiered government combining elements of shared-rule and regional self-rule'.$^{38}$ Federal political systems, on the other hand, are descriptive terms referring to a broad 
category of non-unitary states ranging from quasi-federations and federations, to confederacies (including: federacies, associated statehood, condominiums, leagues and joint functional authorities). Federations are thus but one species of the genus 'federal political system'. In federations according to Watt's classic definition:

1) neither the federal nor the constituent units of government are constitutionally subordinate to the other, i.e., each has sovereign powers derived from the constitution rather than another level of government;

2) each is empowered to deal directly with its citizens in the exercise of legislative, executive and taxing powers and

3) each is directly elected by its citizens. ${ }^{39}$

\section{Structural prerequisites for federations}

How can we test if a country is a federation or not? In light of the above discussion, scholars of federalism have put forward the following structural prerequisites which states must meet before they can be classified as federations: ${ }^{40}$

1) The existence of at least two-tiers of government, both tiers of which have a formal constitutional distribution of legislative, executive and judicial powers and fiscal autonomy,

2) Some form of voluntary convenant or contract among the components normally a written constitution (not unilaterally amendable and requiring for amendment the consent of a significant proportion of the constituent units),

3) Mechanisms to channel the participation of the federated units in decision-making processes at the federal level. This usually involves the creation of a bicameral legislature in which one chamber represents the people at large and the other the component units of the federation,

4) Some kind of institutional arbiter, or umpire, usually a Supreme Court or a Constitutional Court to settle disputes between the different levels of government,

5) Mechanisms to facilitate intergovernmental collaboration in those areas where governmental powers are shared or inevitably overlap. ${ }^{41}$

\section{Decentralism and noncentralism}

Elazar alerts us to yet another vitally important factor in defining federal systems, the differences between the decentralisation to be found in unitary states and the noncentralisation of federal regimes. Decentralisation 'implies a hierarchy - a pyramid of governments with gradations of power flowing down from the top'.

Noncentralisation, on the other hand, 'is best conceptualised as a matrix of governments... where there are no higher or lower power 
centres, only larger or smaller arenas of decision making and action' ${ }^{42}$ Thus, in federations, in contrast to unitary states, regional autonomy is not only devolved but constitutionally guaranteed. ${ }^{43}$ The federal government cannot usurp powers which have been constitutionally devolved to the federal subjects. As Elazar observers, federal systems such as the United States, Switzerland and Canada have such noncentralised systems. Each has, a national government that functions powerfully in many areas for many purposes, but not a central government controlling all the lines of political communication and decision making. In each, the states, cantons or provinces are not creatures of the federal government but, like the latter, derive their authority directly from the people. Structurally, they are substantially immune to federal interference. ${ }^{44}$

\section{Structure, process and culture}

Another important distinction to be made is that between structure and process. Here we refer to the formal structural features of federations, as defined above, and the actual operational procedures put into practice by federal governments. As Elazar stresses, 'the structure of federalism is meaningful only in polities whose processes of government reflect the federal principle ${ }^{\prime}{ }^{45}$ In other words, federal structures may be in place in a polity, and federal principles may be enshrined in a country's constitution, but there may still be no federalism in operation - as was the case, for example in the Soviet Union (see chapter 2). Here, we need to add a cultural dimension to the five structural definitions provided above. A democratic and legalistic culture is required for a democratic federation. As Watts notes, a recognition of the supremacy of the constitution over all orders of government and a political culture emphasising the fundamental importance of respect for constitutionality are therefore prerequisites for the effective operation of a federation. ${ }^{46}$

As I shall show in this study, Russia has adopted all of the key structural trappings of a federation and the Constitution does indeed enshrine many of the key principles of federalism and democracy, but in practice, neither the federal authorities nor the federal subjects have fully lived up to these federal principles. Moreover, in the absence of a democratic political culture in Russia there can be no real federalism. Russia is a federation without federalism.

\section{Symmetrical and asymmetrical federations}

Federations may be further sub-divided into symmetrical and asymmetrical federations. As we discuss below, the Russian Federation has one of the highest levels of asymmetry in the world. Stepan makes the interesting observation that all multinational democracies (with the exception of 
Switzerland) are constitutionally asymmetrical, and all federations that are constitutionally symmetrical are mononational. ${ }^{47}$

The Russian Federation is the largest multinational country in the world incorporating 128 officially recognised ethnic groups and nationalities. As box 1.1 shows there are 89 federal subjects, 57 of which are territorially defined entities, and 32 of which are ethnically defined, including 21 ethnic republics and 11 national autonomies. Thus, it is hardly surprising that Russia is also constitutionally asymmetrical. However, as Smith notes, it is not asymmetry per se, but rather, the extent of Russia's asymmetry that marks it out from other federations. ${ }^{48}$

There are three types of asymmetry in federal states: (1) socioeconomic; (2) political; and (3) constitutional. And whilst elements of the first two are present in all federations, this is not the case with the third type. Russia possesses high levels of asymmetry in all three areas.

\section{Socio-economic asymmetry}

Socio-economic asymmetry is, of course, present in every federation, referring as it does to such factors as, the number of federal subjects, their size, population, economic status, and wealth. Whilst it is impossible to avoid some degree of socio-economic asymmetry, where there are high levels of inequality between regions, tensions and even outright conflict between federal subjects may arise. Such tensions are liable to be particularly rife in those federations where one subject has a predominant position, such as was the case with the Russian Soviet Federative Socialist Republic (RSFSR) in the USSR, and is currently the case with Moscow city within the Russian Federation (see table 1.1 and chapter 5).

The 89 different components of the Russian federation vary widely in the size of their territories and populations. Thus for example the republic of Sakha has a territory which is 388 times the size of the republic of North Osetiya. The population of Moscow (8.5 million) is 443 times greater than that of the sparsely populated Yevenk Autonomous Okrug. ${ }^{49}$ The thirty-two ethnically defined 'subjects' also vary considerably in their ethnic composition (see chapter 4).

Box 1.1 Federal structure of the Russian Federation

Ethnically defined subjects (32)

21 Ethnic republics

Territorially, defined subjects (57)

10 Autonomous okrugs

6 Krais

1 Autonomous oblast

49 Oblasts

2 Federal cities (Moscow and St Petersburg) 
Table 1.1 Asymmetry of population of fully fledged constituent units in federal systems

\begin{tabular}{|c|c|c|c|c|c|c|}
\hline & $\begin{array}{l}\text { No. of } \\
\text { units }\end{array}$ & Largest unit & $\begin{array}{c}\% \text { of } \\
\text { federation }\end{array}$ & $\begin{array}{c}\text { Smallest } \\
\text { unit }\end{array}$ & $\begin{array}{c}\% \text { of } \\
\text { federation }\end{array}$ & $\begin{array}{c}\text { Population } \\
\text { difference between } \\
\text { largest and } \\
\text { smallest units }\end{array}$ \\
\hline Russia & 89 & Moscow & 5.8 & Yevenk AO & 0.01 & 443.0 \\
\hline India & 25 & Uttar Pradesh & 16.4 & Sikkim & 0.05 & 342.6 \\
\hline Switzerland & 26 & Zurich & 17.2 & Appenzell & 0.20 & 84.2 \\
\hline Canada & 10 & Ontario & 37.8 & $\begin{array}{l}\text { Prince } \\
\text { Edward }\end{array}$ & 0.46 & 81.5 \\
\hline United States & 50 & California & 11.9 & Wyoming & 0.18 & 65.8 \\
\hline Spain & 17 & Andalucia & 17.9 & La Rioja & 0.68 & 26.4 \\
\hline Germany & 16 & $\begin{array}{l}\text { N. Rhine } \\
\text { Wesphalia }\end{array}$ & 21.8 & Bremen & 0.84 & 26.0 \\
\hline Australia & 6 & $\begin{array}{l}\text { New South } \\
\text { Wales }\end{array}$ & 33.7 & Tasmania & 2.67 & 12.6 \\
\hline Malaysia & 13 & Perak & 12.8 & Perlis & 1.06 & 12.0 \\
\hline Belgium & 3 & $\begin{array}{l}\text { Flemish } \\
\text { region }\end{array}$ & 57.6 & Brussels & 9.52 & 6.0 \\
\hline Austria & 9 & Vienna & 19.6 & Burgenland & 3.51 & 5.6 \\
\hline Pakistan & 2 & East Pakistan & 54.0 & $\begin{array}{l}\text { West } \\
\text { Pakistan }\end{array}$ & 44.16 & 1.2 \\
\hline
\end{tabular}

Source: Ronald Watts, Comparing Federal Systems (Montreal; Kingston; London; Ithaca: McGillQueen's University Press, 2nd edn, 1999), p. 64 (amended version with my figures for Moscow and Yevenk added to the original table).

There are also considerable variations amongst the subjects of the federation in their levels of industrial development, per capita income and expenditure, average wages and other socio-economic indices such as the numbers of unemployed and the percentage of citizens living below the poverty line (see chapter 5). Thus, for example, in the mid-1990s the level of per capita income in the oil rich Yamala-Nenetsk Autonomous Okrug was 178 times greater than in the republic of Ingushetiya. The volume of gross regional products per capita in Yamalo-Nenetsk is 36 times higher than in Ingushetiya. In comparison, the volume of national income varies by only 1.3 times in the USA. And income per capita varies only 1.5 times in the German Lander. ${ }^{50}$

In 1999 unemployment varied across the Russian Federation from 5.6 
per cent in Moscow city to 51.8 per cent in refugee flooded Ingushetiya. The disproportionate economic strength of Moscow city is graphically illustrated by the fact that tax payments from the city regularly comprises about one-third of the total tax revenues going to the federal budget (see chapter 5).

\section{Political asymmetry}

Political asymmetry refers to the inequalities of representation and political status which federal subjects gain either from their socio-economic status or which they may develop from more overtly political factors such as patron-client relations. Federal subjects which are economically powerful will usually also have more political status. This is clearly seen in Russia where rich donor subjects (regions which pay more taxes into the federal coffers than they receive back in income from the federal budget) have been able to make more political demands on the centre than the impoverished 'recipient regions' who depend on the centre for economic survival (see chapter 5).

\section{Constitutional asymmetry}

Constitutional asymmetry, which is not found in all federations, refers to 'constitutionally embedded differences between the legal status and prerogatives of different sub-units within the same federation' ${ }^{51}$ One example is the case of the Canadian Federation, where the province of Quebec has been granted exclusive powers over language, education and immigration policy, which for other Canadian provinces are the exclusive power of the federal government. Other countries with such constitutional asymmetries are: Belgium, India, Malaysia and Spain. ${ }^{52}$

Constitutional asymmetry is also a major feature of Russian federalism. Even although the Russian Constitution declares that all subjects are constitutionally equal (article 5) in fact the twenty-one ethnic republics have been granted far greater powers than the other subjects of the federation. Such constitutional inequalities have fundamentally undermined the authority of the Constitution and led to power struggles between the ethnic republics and the other territorially defined subjects. There have also been attempts by some regions to unilaterally elevate their status to that of the republics. Russian nationalists have pressed for Russia's dual ethno-territorial form of federalism to be abolished in favour of a new federation based solely on territorial criteria (see chapters 2 and 3). And bilateral treaties signed between some privileged subjects and the federal government has widened constitutional asymmetry even further (see chapter 3). 


\section{Origins and types of federations}

The origins of federal states and the specific ways in which they were formed are of crucial importance in determining the "character of the distribution of powers' in federations. Federal states may emerge 'from below' through the voluntary amalgamation of independent states (e.g., the US, Switzerland and Australia), or on the contrary they may result from top-down constitutional changes made to unitary states to prevent their collapse (India, Belgium, Spain). Stepan calls the former types which emerge from below as 'coming together federalism' and the latter topdown varieties as 'holding-together federalism' ${ }^{53}$ Stepan also defines a third category, 'putting together federalism', which entails 'a heavily coercive effort by a nondemocratic centralizing power to put together a multinational state, some of the components of which had previously been independent states ${ }^{\prime}{ }^{54}$ The USSR was a classic example of this type of federalism. Those federations which arise out of bottom-up bargaining ('revolutions from below') generally cede more powers to their federal subjects than those which come about as the result of top-down bargaining amongst elites ('revolutions from above'). As we discuss in chapter 3 Russia's Constitution was imposed from above. Yeltsin's 'Presidential' Constitution of December 1993 granted the federal government sweeping powers over all of the major aspects of the economy and polity (article 71), and whilst aticle 72 lists a number of concurrent powers to be shared between the federal government and the regions, no exclusive powers were given to the federal subjects. The regions were only granted residual powers (article 73).

\section{Federalism and democracy}

Scholars of federalism have also stressed the positive relationship between federalism and democratisation. For Watts, federalism is inherently democratic as it presumes, 'the voluntary consent of citizens in the constituent units, non-centralisation as a principle expressed through multiple centres of political decision making, open political bargaining ... the operation of checks and balances to avoid the concentration of political power, and a respect for constitutionalism ${ }^{\prime} .^{55}$

For King, federation and democracy are but two sides of the same coin, and for true federalism to function relations between the centre and regions must be grounded in constitutional law and democratic representation. In particular, the constituent units of the federation must be incorporated into the decision-making procedures of the central government, on some 'constitutionally entrenched basis' ${ }^{56}$ King posits four essential attributes of a democratic federation: 
(a) Its representation is preponderantly territorial; (b) and this territorial representation is characteristically secured on at least two sub-national levels; (c) the regional units are incorporated electorally, perhaps otherwise, into the decision procedure of the national centre; and (d) the incorporation of the regions into the decision procedure of the centre can only be altered by extraordinary constitutional measures, not for example by resort to a simple majority vote of the national legislature, or by autonomous decision of the national executive. ${ }^{57}$

Thus, King, Watts, Elazar and others signal what has tended to become accepted as the norm, 'only those states whose governments are subordinate to constitutional law and which therefore practice democracy are judged as true federations' ${ }^{58}$ We shall return to a discussion of federalism and democracy in the conclusion.

\section{Outline of study}

In this study I argue that Russia's weak and asymmetrical form of federalism has played a major role in thwarting the consolidation of democracy. Just as founding elections and the 'freezing' of party systems are highly important for the subsequent trajectory of transitional societies, I would argue that the 'freezing' of a particular set of federal (both constitutional and unconstitutional) relations over the period 1991 to 1993, has been of no less importance in shaping the present contours of Russia's semi-authoritarian form of governance. The result has been the formation of a highly asymmetrical federation with a weak federal state and powerful federal subjects. And political and economic relations have now superseded legal and constitutional procedures as the basis of centre-periphery relations.

Below I discuss the major factors which have been instrumental in bringing about the current chronic weakness of 'state capacity' at the federal level and which, in turn, have thwarted the development of democracy in Russia. I also argue that it is too simplistic to test the level of democratisation in Russia by merely studying national level politics. As we shall see (in chapters 6-7 and 9) there are many different kinds of political regime in operation in Russia ranging from quasi-democracies to 'delegative democracies'. In chapters 2 and 3 we examine the origins of Russia's ethno-territorial form of federalism and the development of constitutional and political asymmetry in the Yeltsin era. In chapter 4 we turn to a study of the ethnic make-up of the federation and the prospects for ethnic secessionism. Socio-economic asymmetry and fiscal federalism are discussed in chapter 5 . In chapters 6-7 we turn to an examination of political asymmetry. Regional elections and the problems of developing a viable party system are discussed in chapter 6 and in chapter 7 we examine the struggle between executive and legislative bodies of power. 
Chapter 8 provides an examination of Putin's radical reform of the federal system. Finally, in chapter 9 we examine the problems of consolidating democracy in Russia's regions and republics.

\section{Notes}

1 D. Ch. Shin, 'On the third wave of democratisation: a synthesis and evaluation of recent theory and research', World Politics, 47 (October, 1994), 136.

2 For excellent reviews of this literature see, A. Hadenius, Democracy and Development (Oxford: Oxford University Press, 1992); S. M. Lipset, 'The social requisites of democracy revisited', American Sociological Review (1994), 59; G. L. Munck, 'Democratic transitions in comparative perspective', Review Article, Comparative Politics (April 1994); K. L. Remmer, 'New theoretical perspectives on democratisation', Review Article, Comparative Politics (October 1995), 103-22; D. Ch. Shin, 'On the third wave of democratisation: a synthesis and evaluation of recent theory and research', World Politics, 47 (October 1994), 135-70; G. Sorensen, Democracy and Democratisation (Boulder: Westview Press, 1993).

3 D. Rueschemeyer, E. H. Stephens and J. D. Stephens, Capitalist Development and Democracy (Chicago: University of Chicago Press, 1992).

4 S. Huntington, The Third Wave: Democratisation in the Late Twentieth Century (Norman: University of Oklahoma Press, 1991); R. Putnam, Making Democracy Work: Civic Traditions in Modern Italy (Princeton: Princeton University Press, 1993).

5 T. A. Koelbe, 'The new institutionalism in political science and sociology', Comparative Politics (January 1995), 231-43; D. C. North, Institutions, Institutional Change and Economic Performance (Cambridge: Cambridge University Press, 1990); J. March and J. Olson, Rediscovering Institutions: The Organisational Basis of Politics (New York: The Free Press, 1989); S. Steinmo, K. Thelen and F. Longstreth (eds), Structuring Politics: Historical Institutionalism in Comparative Analysis (New York: Cambridge University Press, 1992); B. Guy Peters, Institutional Theory in Political Science (London: Cassell, 1999).

6 A. Lijphart, Electoral Systems and Party Systems (Oxford: Oxford University Press, 1994).

7 J. J. Linz, 'The perils of presidentialism', Journal of Democracy, 1 (Winter 1990); J. J. Linz and A. Valenzuela (eds), The Failure of Presidential Democracy: Comparative Perspectives (Baltimore: Johns Hopkins University Press, 1994); S. Mainwaring, 'Presidentialism, multipartism, and democracy', Comparative Political Studies, 26:2 (1993), 198-228; M. Shugart and J. M. Carey, Presidents and Assemblies (Cambridge: Cambridge University Press, 1992); A. Stepan and C. Skach 'Constitutional frameworks and democratic consolidation: parliamentarianism versus presidentialism', World Politics, 46 (1994), 1-22.

8 G. Sartori, Parties and Party Systems: A Framework for Analysis (Cambridge: Cambridge University Press, 1976); A. Ware, Political Parties and Party Systems (Oxford: Oxford University Press, 1996).

9 D. Rustow, 'Transitions to democracy: toward a dynamic model', Comparative Politics, 2:3 (1970). 
10 D. Held, Democracy and the Global Order (Cambridge: Polity, 1995); G. Pridham, G., Herring and E., Sanford, The International Dimension of Democratisation in Eastern Europe (London: Leicester University Press, 1994).

11 T. L. Karl and P. C. Schmitter, 'Modes of transition in Latin America, Southern and Eastern Europe', International Social Science Journal, 128 (1991), 269-84; S. Mainwaring, G. O'Donnell and S. J. Valenzuela (eds), Issues in Democratic Consolidation (Notre Dame, Indiana: University of Notre Dame Press, 1986).

12 J. Higley and G. Lengyel, Elites after State Socialism: Theories and Analysis (Lanham, Boulder, New York, Oxford: Rowman and Littlefield, 2000); J. Higley and R. Gunther (eds), Elites and Democratic Consolidation in Latin America and Southern Europe (Cambridge: Cambridge University Press, 1992); J. Higley, J. Pakulski and W. Wesolowski, Postcommunist Elites and Democracy in Eastern Europe (Houndmills, Basingstoke: Macmillan, 1998); J. Kullberg, J. Higley and J. Pakulski, 'Elites, institutions and democratisation in Russia and Eastern Europe', in G. Gill (ed.), Elites and Leadership in Russian Politics (New York: St Martin's Press, 1988); D. Lane and C. Ross, From Communism to Capitalism: Ruling Elites From Gorbachev to Yeltsin (New York: St Martin's Press, 1999).

13 Higley and Gunther, Elites and Democratic Consolidation.

14 Lane and Ross, From Communism to Capitalism.

15 J. J. Linz and A. Stepan, Problems of Democratic Transition and Consolidation (Baltimore: Johns Hopkins University Press, 1996); J. J. Linz and A. Stepan, 'Toward consolidated democracies', Journal of Democracy, 7:2 (1996), 14-33; G. O'Donnell, 'Illusions about consolidation', Journal of Democracy, 7:2 (April 1996), 34-51; A. Schedler, 'What is democratic consolidation', Journal of Democracy, 9:2 (1998), 91-107.

16 D. Ch. Shin, 'On the third wave'; G. Di Palma, To Craft Democracies: An Essay on Democratic Transitions (Berkley: University of California Press, 1990).

17 With the notable exceptions of the excellent studies by Alfred Stepan. See, A. Stepan, 'Russian federalism in comparative perspective', Post-Soviet Affairs, 16:2 (2000); and also his, 'federalism and democracy: beyond the U.S. model', Journal of Democracy, 10:4 (October, 1999).

18 R. A. Dahl, Polyarchy: Participation and Opposition (New Haven: Yale University Press, 1971), p. 3. Cited in Sorenson, Democracy and Democratisation, p. 12.

19 L. Diamond, J. J. Linz and S. M. Lipset (eds), Democracy in Developing Countries: Volume 4: Latin America (Boulder: Lynne Rienner, 1989), p. xvi.

20 Sorenson, Democracy and Democratisation, p. 12.

21 O'Donnell, 'Illusions about consolidation', 35.

22 Ibid., 36.

23 D. Beetham, Democracy and Human Rights (Cambridge: Polity Press, 1999), pp. $154-5$.

24 Ibid.

25 A. Schedler, 'What is democratic consolidation?', Journal of Democracy, 9:2 (April 1998), 91.

26 Beetham, Democracy and Human Rights, pp. 69-70.

27 G. O'Donnell, 'Challenges to democratisation in Brazil', World Policy Journal, 5 (Spring 1998), 257. Quoted in Shin, 'On the third wave', 145.

28 Linz and Stepan, 'Toward consolidated democracies', 15.

29 Ibid., 71. 
30 Schedler, 'What is democratic consolidation?', 101.

31 S. J. Valenzuela in, S. Mainwaring, G. O'Donnell and S. J. Valenzuela (eds), Issues in Democratic Consolidation (Indiana: University of Notre Dame Press, 1992), p. 70, quoted in Shin, 'On the third wave', 145.

32 Huntington, The Third Wave, p. 263.

33 Linz and Stepan, 'Toward consolidated democracies', 17.

34 Ibid.

35 Z. Gitelman 'The democratisation of Russia in comparative perspective', in S. White, A. Pravda and Z. Gitelman (eds), Developments in Russian Politics - 4 (Basingstoke: Macmillan, 1999).

36 D. J. Elazar, Exploring Federalism (Tuscaloosa and London: The University of Alabama Press, 1987), p. 6.

37 G. Smith, Federalism: The Multiethnic Challenge (London, New York: Longman, 1995), p. 1.

38 R. Watts, Comparing Federal Systems (Montreal and Kingston: McGill-Queen's University Press, 2nd edn, 1999), p. 6.

39 Ibid., p. 7.

40 Watts, Comparing Federal Systems; A. Lijphart, Patterns of Democracy: Government Forms and Performance in Thirty-Six Countries (New Haven and London: Yale University Press, 1999), D. Elazar, Exploring Federalism; F. Requejo, 'National pluralism and federalism: four potential scenarios for Spanish plurinational democracy', Perspectives on European Politics and Society 2:2 (2001); D. Elazar, Federal Systems of the World: A Handbook of Federal, Confederal and Autonomy Arrangements (Harlow: Longman, 1991).

41 D. Kempton also adds five 'beneficial conditions for the maintenance of federalism': (1) symmetry among the components, (2) decentralised federal political parties, (3) a noncentralised bureaucracy, (4) democracy and (5) economic coordination. See, D. Kempton, 'Russian federalism: continuing myth or political salvation', Demokratizatsiya, 9:2 (Spring 2001), 231.

42 Elazar, Exploring Federalism, pp. 34, 35-7.

43 Smith, Federalism: The Multi-Ethnic, p. 7.

44 Elazar, Exploring Federalism, p. 35.

45 Ibid., p. 67.

46 Watts, Comparing Federal Systems, p. 99.

47 Ibid., p. 31.

48 G. Smith, The Post-Soviet States: Mapping The Politics of Transition (London, Sydney, Auckland: Arnold, 1999), p. 140.

49 A. N. Lebedev, Status Sub'ekta Rossiiskoi Federatsii (Moscow: Institute of State and Law, 1999), p. 24.

50 G. Marchenko, 'Nuzhno li perekraivat' Rossiyu?', in Olga Sidorovoch (ed.), Rossiiskii Konstitutsionalism: Politicheskii Rezhim v Regional'nom Kontekste: Sbornik Dokladov (Moscow: MONF, 2000), pp. 72-3.

51 A. Stepan, 'Russian federalism in comparative perspective', Post-Soviet Affairs, $16: 2(2000), 142$.

52 Watts, Comparing Federal Systems, p. 68.

53 A. Stepan, 'Federalism and democracy: beyond the U.S. model', Journal of Democracy, 10:4 (October, 1999), 22-3.

54 Ibid., 23. 
55 Ibid., 14.

56 M. Burgess and A. G. Gagnon (eds), Comparative Federalism and Federation (New York, London, Harvester Wheatsheaf: 1993), p. 93.

57 P. King, 'Federation and representation', in Burgess and Gagnon, Comparative Federalism, p. 94.

58 Smith, Federalism: The Multi-Ethnic Challenge, p. 8. 